\title{
XX. A sensitive mercury barometer
}

\section{Frederick Guthrie}

To cite this article: Frederick Guthrie (1877) XX. A sensitive mercury barometer, Philosophical Magazine Series 5, 3:16, 139-141, DOI: 10.1080/14786447708639206

To link to this article: http://dx.doi.org/10.1080/14786447708639206

\section{曲 Published online: 13 May 2009.}

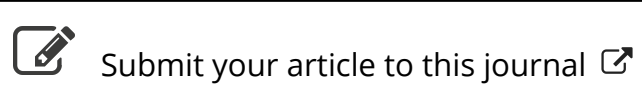

\footnotetext{
Џll Article views: 2
}

Q View related articles $\longleftarrow$ 


\section{[ 139$]$ \\ XX. A Sensitive Mercury Barometer. By Frederick Guthrie*.}

THE object aimed at is to get a barometer which shall conbine great sensibility with sufficient compactness. The barometers depending upon the weight of liquid columns are, unless the liquid is mercury, of unwieldy length. Descartes suggested a modification of the mercurial barometer in which the air-supported column of liquid consists of two liquids, the lower one being mercury and the upper one water holding tartar-emetic in solution to ensure the expulsion of air (fig. 1). Now that we know various liquids, notably hy- Fir. 1. drocarbons, which have no sensible vapour-tension at atmospheric temperatures, it is surprising that this form has not been reintroduced. It appears, however, to be little known. It was suggested to me by a friend; and I made one containing glycerine and used it with success for some months before I was aware of its having been suggested by Descartes. The sensibility of such a barometer would obviously be, if the upper liquid were without weight, directly proportional to the ratio between the sectional areas of the cylindrical chamber and the upper tube (if also the open limb were of infinite area). But, the upper liquid having weight, the limit of sensibility is the comparative density of the mercury and liquid (say 16:1). Accordingly this limit is reached when the cylindrical chamber has four times the diameter of the upper tube.

By inclining the top part of the supported co-

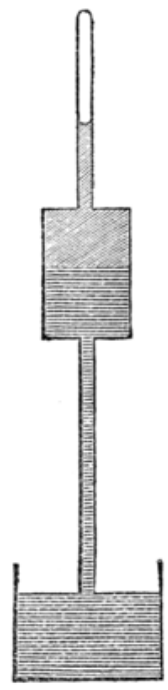
lumn a theoretical increase of sensibility is obtained; butpractically, on account of the dragging on the column and for other reasons, this device is not in use for exact measurements. The multiplication of motion caused by applying a float connected with a wheel, as in the common weather-glass, is for similar reasons to be discarded for such purposes. Aneroid barometers are of exceedingly convenient form, but are of course saddled with the objection that the metal chamber is never perfectly elastic, so that they require frequent comparison with standard mercurial ones.

My friend the late B. F. Duppa devised a barometer in which the cistern or open limb was dispensed with, and was replaced by an open horizontal capillary tube. The free sur-

* Communicated to the Physical Society, Jan. 20, 1877. 
face of the mercury in the capillary tube would then move at a rate proportional to the sectional areas of the vacuum end and the capillary. I believe this plan was not found to answer, on account of the oxidation of the free end of the mercury.

The plan which I submit, and which in the models I have made and have had made appears to succeed well, more resembles that of M. Duppa than of any other with which I am acquainted. One form, shown in fig. 2 , made for me by Messrs. Cetti, of Brooke Street, Holborn, consists of an ordinary barometer-tube, B, 6 millims. in internal diameter, connected by a flat horizontal spiral, $\mathrm{S}$, of 2 millims. internal diameter, with the open tube $\mathrm{C}$ of the same diameter as $\mathrm{B}$. In $\mathrm{S}$ is a bubble of air, $a$, at such a distance from $\mathrm{B}$ that it cannot enter $B$ when the mercury in that tube is at the top. The motion of the bubble is, of course, 9 times as fast as that of the level of the mereury in either limb, or $4 \frac{1}{2}$ that of the true barometric variation. The object of bringing $\mathrm{B}$ and $\mathrm{C}$ together is to avoid as much as possible the effect of the relative differences of height on change of place. In another form (which is being made by $\mathrm{Mr}$. Hicks, of Hatton Garden), the limb $\mathrm{C}$ is made to enclose hermetically the limb B. This should bring the effect of such relative tilting to a minimum.

Fig. 2.

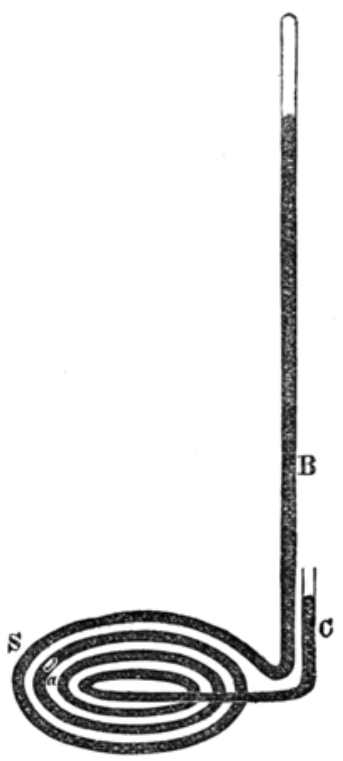

In one which I have myself made, the tube $S$ being straight and placed on a stone mantlepiece, a drop of sulphuric acid is employed instead of the air-bubble. It has the effect of making the motion rather more nimble, but is perhaps not quite so trustworthy for exact measurements, because the wetting of the tube by the liquid causes some inconstancy in its calibre. $A$ tube $S$ of 2 millims. internal diameter, connected with a barometer-tube having at its upper mercurial surface a diameter of 20 millims., would exaggerate barometric motion 100 times; and of course the sensibility would approach the nearer to twice this, the greater the diameter of the open limb. There is indeed absolutely no theoretical limit to the possible sensibility. It must be left to practical glass-workers to determine whether a spiral form is the best for the tube $S$, or whether a series of parallel tubes joined alternately end to end are to be 
preferred. According to Professor Dewar, who has had great experience in the use of such tubes for similar purposes, it would not be advisable to have the $S$ tube less than 2 millims. internal diameter. In all cases, on account of the unavoidable irregularities in so long a tube, I presume as many as possible comparisons should be made with a standard barometer and the intermediate graduations introduced by interpolation. In the straight one mentioned above, the gap in the mercury thread is seen through a lens to be in constant agitation.

XXI. Notices respecting New Books.

The Vocabulary of Philosophy, Mental, Moral, and Metaphysical: with quotations and references for the use of Students. By William Flemima, D.D., late Professor of Morcel Philosophy in the Vniversity of Glasgow. Third Edition. Edtited by HENRY CaLderwood, LLL.D., Professor of Moral Plitrosophy in the Uitiversity of Edinburgh. Loudon: Charles Griffin and Compasy, Stationers' Hall Court. 1876. Crown 8vo. 540 pages.

THE object of this work is sufficiently deseribed by its title-page.

The editor justly remarks that the fact of its having "soon passed through two editions shows that it has supplied a want felt by those entering upon philosophic study." It contains a number of short articles explaining and illustrating the meaning of about 800 words. The articles vary in length from six or eight lines to two or three pages. In one case an article (that on Idea) extends to seven pages. The exposition of the meaning of the words is mainly effected by illustrative extracts, a method which gives rariety and interest to the discussion. Indeed the book might be fairly called an entertaining book, in the way in which books of detached "Thoughts," or "Guesses at Truth," or "Table Talk" are entertaining. Besides, words are used with different shades of meaning by different authors according to the cast of the opinions they have embraced; and this difference is best shown by actual quotation.

An account of a single article will sufficiently exhibit the method of the book ; we will take that on Experience. It consists, in the first place, of a statement that, "according to Aristotle (Analyt. Poster.ii. 19), from sense comes memory, but from repeated remembrance of the same thing we get experience." Wolf and Wlately are quoted to bring out the meaning of the word more fully. Locke is then quoted to exhibit the riew that experience is the sole source of knowledge; and Sewell for the opposite view, that men have knowledge à priori. The article ends with quotations from Boscovich and Herschel, pointing out the distinction between experience derived from observation and from experiment. This is the article as originally written by Dr. Fleming. The editor, however, has inserted two paragraphs, which are distinguished by being 